\title{
Compositional Similarity of Urban Green Areas in Southeastern Brazil
}

\author{
Ronaldo Oliveira dos Santos ${ }^{1}$ (D), Rubiene Neto Soares ${ }^{1}$ (D), \\ Breno Marques da Silva e Silva ${ }^{1}$
}

${ }^{1}$ Universidade do Estado do Amapá - UEAP, Macapá/AP, Brasil

\begin{abstract}
Urban afforestation greatly contributes to the ex situ conservation of native species in urban centers of Brazil. In this way, the aim of the present work was to analyze the similarity of the arboreal-shrub flora among urban afforestation in southeastern Brazil. For this analysis, a binary matrix with data of 283 species present in 20 municipalities in the Southeastern Region of Brazil was adopted, in which the Principal Component Analysis (PCA) was also used aiming at enabling refinement in the grouping obtained by the floristic similarity (FS) of Sørensen with similarity from values provided by PCA. FS among municipalities was intermediate, but the highest similarity of urban flora was found among the geographically closest municipalities. In the southeastern region, 283 species were recorded, being distributed in 71 botanical families, with Fabaceae having the largest number of species, and with emphasis on the predominance of exotic plants over native plants.
\end{abstract}

Keywords: aggregation analysis, urban afforestation, multivariate techniques. 


\section{INTRODUCTION}

Urban afforestation is essential for the ecological, aesthetic and socioeconomic quality of urban spaces, since it improves the quality of life of cities and their population. In this sense, Souza et al. (2011) reported that considering the existence of economic and social benefits of trees in cities is only a logical process, since they offer ecological (climate and pollution), biological (physical health) and psychological (mental health) benefits.

Despite the understanding about the importance of establishing afforestation planning in urban centers, advances regarding effective public policies for the development of planning associated with urban afforestation in Brazilian cities are scarce. This fact is corroborated by Gonçalves \& Paiva (2004), who affirmed that despite the enormous diversity of native species of each region, planners have generally preferred the use of exotic species from other regions of the country and also from abroad.

In this context, the proposal of implanting arboreal-tree species in urban spaces only considering the beautification that they provide is a misguided way of planning the green areas of cities. For urban afforestation to be efficient and beneficial, it is essential that species are properly selected (Castro et al., 2011). In this regard, the management agencies of cities should be familiar with the native flora of the region in order to propose afforestation plan prioritizing native species in detriment of the introduction of exotic species inserted in the urban landscape.

A possible justification for the large use of exotic species is the lack of information on Brazilian flora and its landscape potential, especially regarding endangered species (Silva \& Perelló, 2010). For this reason, floristic-comparative studies are essential to identify and facilitate the understanding of the flora in urban spaces (Fischer et al., 2016), which would provide a foundation for evaluating the environmental heterogeneity and guidelines for defining strategies for afforestation planning projects in the central areas of avenues, public squares and municipal parks (Oliveira et al., 2016).

The use of multivariate statistics is an important technique to simultaneously explore the relationship among qualitative and quantitative variables, and its use covers different fields of knowledge (Ferreira et al., 2008). In forestry science, specifically in the field of Forestry related to afforestation and landscape, studies that make use of this tool to compare urban forest between regions or even between municipalities within the same state are still scarce.

The study by Cupertino \& Eisenlohr (2013) conducted using data regarding the arborization of 17 Brazilian university campuses draws attention to the number of exotic species used by educational institutions (42.6\%), and although the proportion of native species remained higher (57.4\%), the expressive use of non-native species still prevails. In this context, cluster analysis based on floristic surveys of urban spaces in different Brazilian regions has proven to be an adequate technique for planning urban afforestation, since it provides a more detailed diagnosis of the floristic particularities of each region, thus allowing broad comparisons based on qualitative and quantitative data of species.

In view of the above, the aim of this study was to perform a comparative analysis of arboreal-shrub flora used in the urban area of cities in Southeastern Brazil in order to determine: (i) Are more native species or exotic species being used in this region?;(ii) What are the key species for floristic similarity?; (iii) Is floristic similarity associated with regional issues (geographical proximity between states)?; and (iv) Is it possible to refine the similarity analysis through the application of Principal Component Analysis (PCA)?

\section{MATERIAL AND METHODS}

A survey of floristic studies on urban afforestation (squares, sidewalks, central beds, roundabouts or any public road) in the states of São Paulo, Minas Gerais, Rio de Janeiro and Espírito Santo in Southeastern Brazil was conducted by digital consultation of scientific studies (books, monographs, dissertations, theses, expanded abstracts, articles and scientific notes) published by publishers, events or scientific journals, excluding works with incomplete lists of species or without their respective frequencies (Figure 1).

Arboreal-shrub species were included for database construction and herbaceous plants, palm trees and vines were excluded, seeking data standardization to be extracted. In addition, undetermined taxa were 


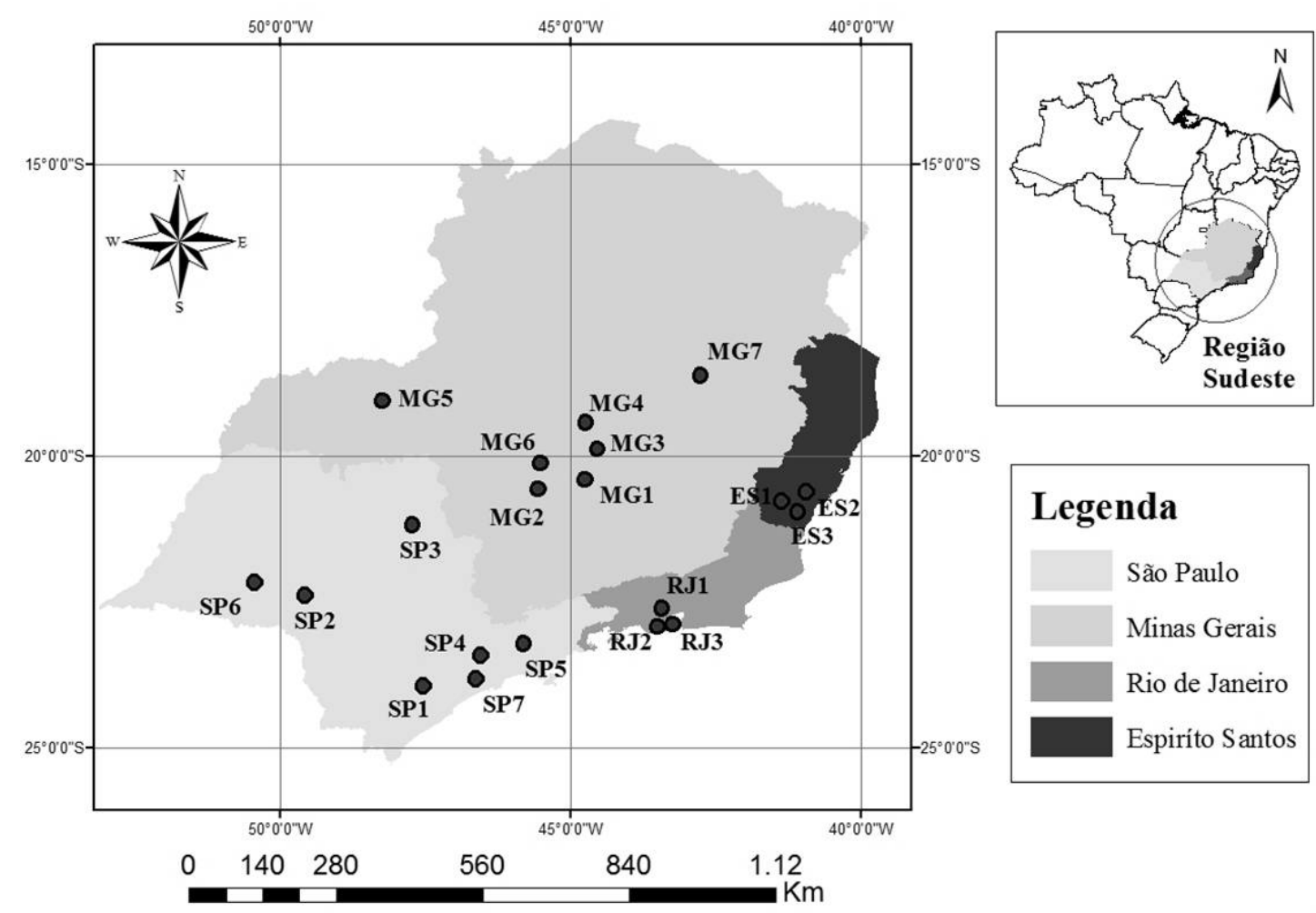

Figure 1. Location of floristic areas compiled from the afforestation of urban centers in southeastern Brazil. Caption: SP1 - Salto de Pirapora (Benatti et al., 2012), SP2 - Garça (Nunes et al., 2013), SP3 - Ribeirão Preto (Romani et al., 2012), SP4 - São Paulo (Souza et al., 2016), SP5 - Jacareí (Faria et al., 2007), SP6 - Assis (Rossatto et al., 2008), SP7 - Ipiranga (Rossetti et al., 2010), MG1 - Divinópolis, MG2 - Formiga, MG3 - Itaúna, MG4 - Pará de Minas (Oliveira et al., 2016), MG5 - Uberlândia (Silva et al., 2002), MG6 - Arcos (Oliveira et al., 2016), MG7 - São João Evangelista (Brandão et al., 2011), RJ1-Nova Iguaçu (Rocha et al., 2004), RJ2 - Tijuca (Freitas et al., 2015), RJ3 - Rio de Janeiro (Souza \& Cintra, 2007), ES1 - Jerônimo Monteiro (Silva et al., 2012), ES2 - Vargem Alta (Scaramussa, 2013), and ES3 - Cachoeiro do Itapimirim (Mazioli, 2012).

excluded since congruence among undetermined individuals would be impossible.

The classification system adopted for botanical families was APG III (2009). Spelling, synonymy, popular names, origin and phytogeographic distribution of species were verified using databases of the Brazilian Flora Species List (Forzza et al., 2010; Reflora, 2017) and W3 Tropicos ${ }^{\circ}$ (MOBOT, 2017).

For the similarity analysis, two matrixes were elaborated from the database of the 283 compiled species, one with data regarding presence and absence, and another with frequency data (abundance) of the species. The Sørensen similarity index was used for the presence and absence matrix, which provides greater weight to common species (Cupertino \& Eisenlohr,
2013). The agglomerative hierarchical grouping method was used in elaborating the dendrogram, with links by the average linkage method (UPGMA) (Felfili et al., 2011).

The Bray-Curtis index was used to generate a distance matrix (dissimilarity) based on the matrix of native and exotic species abundance, and later, the simple binding method was applied to form clusters. After the formation of clusters, the Mantel test was applied to evaluate whether there was greater similarity between sites with smaller geographic distances. For this, the Bray-Curtis similarity was correlated with data of spatial coordinates of each study site, using the Monte Carlo method with 1000 random permutations to evaluate the significance of the Mantel test (Zar, 2009). 
It should be noted that the binary matrix was also used as input for the Principal Component Analysis (PCA), seeking to compare the cluster efficiency obtained by Sørensen's floristic similarity (simple method) with similarity obtained from values provided by the PCA ordering technique. For this analysis, the same analytical procedure used by Ferreira et al. (2008) was adopted.

The cophenetic correlation coefficient (CCC) was applied to measure the distortion degree of the original matrix dendrogram of the Sørensen coefficient of similarity (phonetic F matrix) and the matrix resulting from the simplification provided by the clustering method (cophenetic $\mathrm{C}$ matrix).The $\mathrm{R}$ software (R Development Core Team, 2014) was used for conducting all statistical analyses through the vegan library (Oksanen et al., 2013).

\section{RESULTS AND DISCUSSIONS}

The survey found a total of 15,207 tree and shrub individuals distributed across 283 species, 204 genera and 71 botanical families. From this total, the state of São Paulo accounted for the largest amount (60.25\%), followed by Minas Gerais (15.39\%), Rio de Janeiro (14.78\%) and Espírito Santo (9.58\%). Regarding the origin of species, it was generally observed that the urban afforestation of the southeastern region of Brazil is composed of 168 exotic species, of which the Lagerstroemia indica (L.) Pers. (Resedá) species stood out, with 1,333 individuals, and the municipality of Garça-SP presented the highest insertion of this shrub into urban spaces with high expressiveness (88.82\%).

Regarding native species, 115 plants were analyzed, in which Licania tomentosa (Benth.) Fritsch (Oiti) showed the greatest abundance of individuals $(2,482)$ in the total survey, and municipalities of Garça-SP, São João Evangeslísta-MG, Uberlândia-MG and Assis-SP showedthe highest proportion of this species in percentage terms: $22.84 \%, 20.10 \%, 17.32 \%$ and $16.56 \%$, respectively.

The most representative botanical family was Fabaceae, accounting for $37.10 \%$ of the total number of species collected throughout the southeastern region of Brazil, and the state of São Paulo presented the highest occurrence of species of this family (Figure 2). Among Leguminoseae, Caesalpinia pluviosa var. peltophoroides (Benth.) G. P. Lewis (Sibipiruna) was the most evident species and shared by all studies analyzed, which is a tree plant of exotic origin well distributed in the Brazilian territory, and largely used for city landscaping.

Regarding the floristic similarity of urban afforestation among the twenty municipalities, it was found that the Sørensen index ranged from 0.00 to 0.70 , indicating greater similarity between Arcos-MG and Divinópolis-MG, and low similarity between the city of São Paulo and the other municipalities (Figure 3). The explanation for the greater similarity between Arcos - (C1) and Divinópolis - (C2) may be related to the fact that common species occurr between the two areas, suggesting a tendency of similar floristic composition, mainly represented by Licania tomentosa

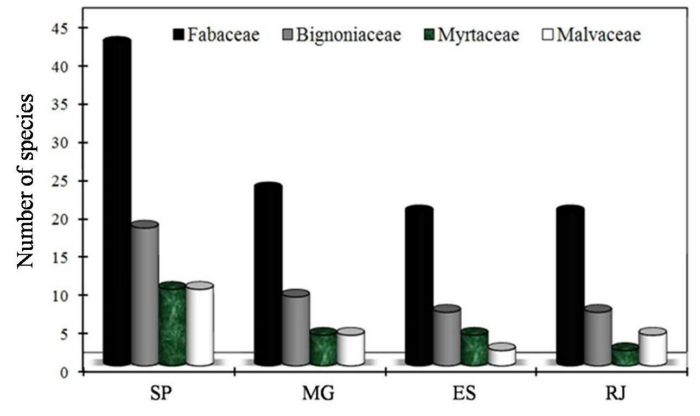

Figure 2. Botanic families that stood out in number of species analyzed in the urban arborization surveys of states in the southeastern region of Brazil. Caption: SP São Paulo, MG - Minas Gerais, ES - Espírito Santo, and RJ - Rio de Janeiro.

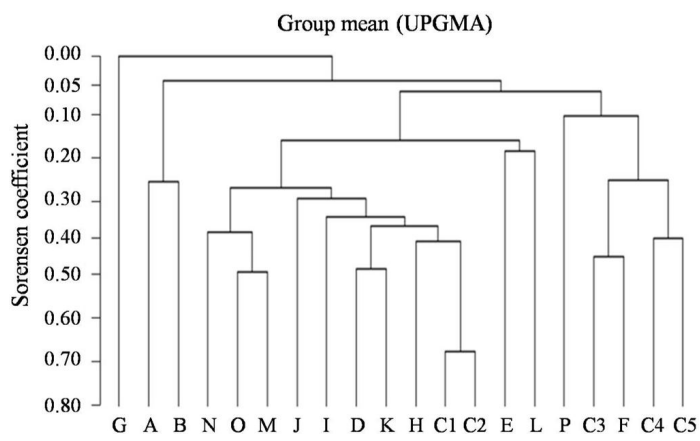

Figure 3. Dendrogram of the urban arborization floristic similarity of the twenty municipalities in the southeastern region of Brazil. Caption: A: Salto da Pirapora; B: Garça; C1: Arcos; C2: Divinópolis; C3: Formiga; C4: Itaúna; C5: Pará de Minas; D: Nova Iguaçu; E: Ribeirão Preto; F: Uberlândia; G: São Paulo; H: Jacareí; I: Tijuca; J: Assis; K: Rio de Janeiro; L: Ipiranga; M: Jerônimo Monteiro; N: Vargem Alta; O: Cachoeiro do Itapimirim; and P: São João Evangelista. 
(Benth.) Fritsch, Ligustrum lucidum W. T. Aiton, Murraya paniculata (L.) Jacq. And Caesalpinia pluviosa var. peltophoroides (Benth.) G. P. Lewis species, of which the first is native and the others are exotic species.

The low similarity observed between São Paulo and the other groups is explained by the significant number of species (67) that only occurred in this city, of which 30 are exotic and 37 are native; and the highest frequency ( 57 individuals) was revealed by Toxicodendron vernicifluum (Stokes) F.A. Barkley (exotic), followed by Tibouchina pulchra Cogn. (35), which is a shrub species native to the Atlantic Rainforest.

This result points to the high variety of species used in the afforestation of cities in the southeastern region of Brazil, and also clarifies that another probable explanation for dissimilarity between cities is the choice of these species, considering that the majority of plants introduced in the afforestation of squares, streets, avenues and municipal parks are exotic (Orfrini et al., 2006) due to their greater availability in the market (Silva \& Perelló, 2010) and popular acceptance, which probably occurs due to the little silvicultural ecological knowledge of native species (Freitas et al., 2015). On the other hand, Castro et al. (2011) reinforce the idea that it is preferable to cultivate native plants in urban spaces of the country, seeking to preserve local biodiversity.

The cophenetic coefficient of 0.74 indicates that $74 \%$ of original similarity matrix data were well reproduced in the dendrogram. In addition, this percentage points out that the cluster method used to synthesize the information of the data set was adequate. This result is in line with the study by Cupertino \& Eisenlohr (2013), in which the authors found cophonetic coefficient value of $79 \%$ in the dendrogram generated by the Sorensen index with floristic similarity data of university campuses in different Brazilian regions.

In the cluster analysis, it is possible to verify that the groups formed point to an aspect of greater similarity between geographically closer sites. This finding is corroborated by the value of the Mantel test $(r=-0.57$, $\mathrm{t}=10.02 ; p=0.025)$, which shows a significant negative correlation between species similarity and the geographic distance among the twenty municipalities under study. Thus, it can be understood that greater distances lead to floristic dissimilarity among the urban environmental flora of the analyzed region (Figure 4). Similarly, Cupertino \& Eisenlohr (2013) observed the influence of distance on the similarity between university campuses in Brazil.

It is important to emphasize that because this is a regional analysis, strong association of floristically similar environments in surveys between neighboring municipalities was expected. Even though it is understood that the flora of urban spaces is conditioned by the criteria established by the governing bodies of each city, it could be considered that the four evaluated states basically (almost) exclusively use the same species in urban landscaping, which probably explains the degree of similarity between adjacent municipalities.

It was found that it is possible to reduce the matrix with data from variables (283 species) for the tenth dimension, with the accumulation of $100 \%$ of the total variation in the first 10 components (Table 1, Figure 5).

The 10 principal components generated were able to explain $100 \%$ of the original data variance, which in turn justifies the use of this method as a way of simplifying the initial matrix structure, thus providing better understanding of variables that most contributed to the similarity analysis. Licania tomentosa (Benth.) Fritsch, Caesalpinia pluviosa var. peltophoroides, Ficus benjamina L., Tabebuia heptaphyla (Vell.) Tol., Hibiscus rosa sinensis L., and Leucaena leucocephalla (Lam.) de Wit. species were the variables that most explained the variance of factorial axes of the linear combination translated by the 10 principal components. Therefore, it could be inferred that the set of substantially uncorrelated orthogonal axes of these variables contain most of the information from the original set (Figure 5).

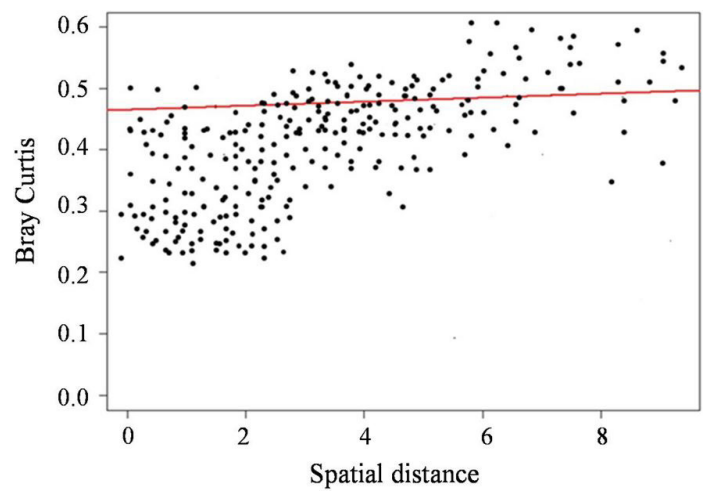

Figure 4. Mantel test based on the Bray Curtis index demonstrating the relationship between spatial distance and dissimilarity of the floristic composition of the twenty municipalities in the southeastern region of Brazil. 
Table 1. Variance estimates (eigenvalues, $\lambda \mathbf{j}$ ) associated with principal components and their relative and accumulated importance.

\begin{tabular}{|cccc|} 
Principal Components & Eigenvalues $(\boldsymbol{\lambda} \mathbf{j})$ & Portion of variance (\%) & $\begin{array}{c}\text { Cumulative portion of } \\
\text { variance }(\%)\end{array}$ \\
\hline 1 & 97.0 & 37.2 & 37.2 \\
\hline 2 & 71.1 & 21.7 & 59.0 \\
\hline 3 & 66.4 & 13.3 & 72.3 \\
\hline 5 & 53.2 & 10.0 & 82.4 \\
\hline 6 & 49.9 & 6.5 & 89.0 \\
\hline 7 & 33.4 & 5.4 & 94.4 \\
\hline 8 & 26.6 & 3.6 & 98.0 \\
\hline 9 & 23.1 & 0.9 & 98.9 \\
\hline 10 & 20.2 & 0.7 & 99.7 \\
\hline
\end{tabular}

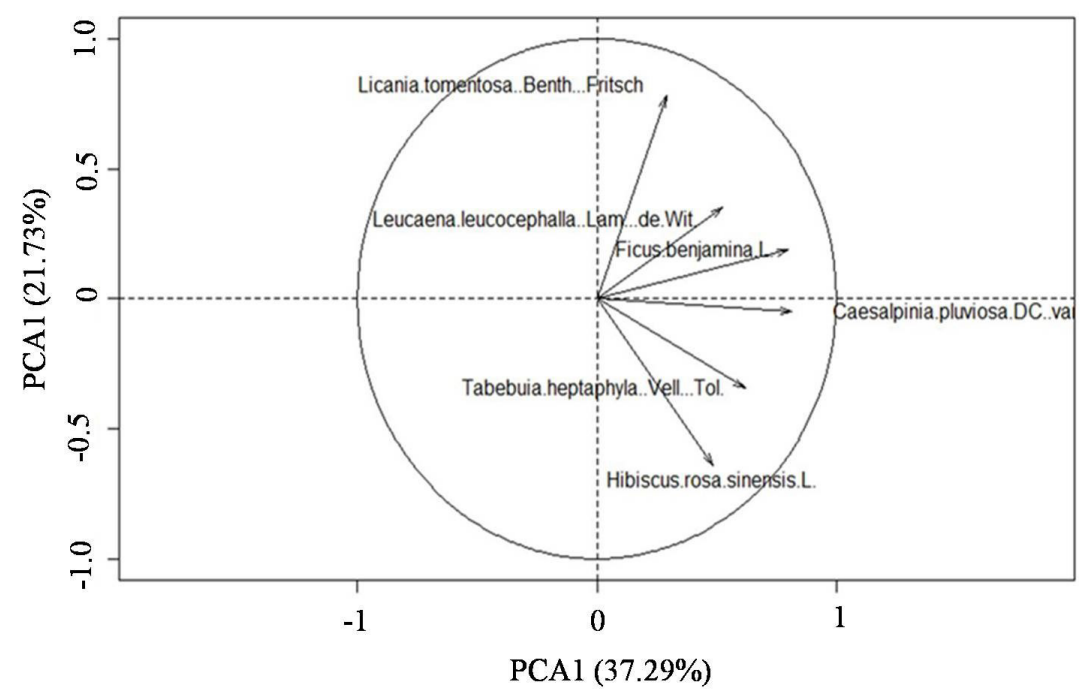

Figure 5. Correlations associated with the first two axes with variables (species) that most explained the variance of factorial axes.

A probable explanation for the fact that these species present greater degree of importance in the analysis is because they are well represented in terms of frequency in each municipality analyzed, in which Licania tomentosa (oiti) (as previously mentioned) was the species that presented the greatest number of individuals in the region. This species is a typical tree of the Atlantic Forest (Monteiro et al., 2012), with a sturdy canopy that provides large shaded areas, and therefore is the preferred species used in squares, streets and avenues, mainly in the cities in the northern and the coastal regions of Brazil (Lorenzi, 2008).

In general, the precise formation of four groups based on the Phenon line at 35\% was observed in the dendrogram constructed from values provided by the first 10 PCA components. The formation of a large cluster encompassing the urban flora areas of $\mathrm{H}, \mathrm{D}, \mathrm{I}, \mathrm{K}, \mathrm{C} 5, \mathrm{C} 1, \mathrm{C} 2, \mathrm{C} 4$ and C3, which presented expressive floristic similarity degree among themselves was also observed (Figure 6). Correct formation of clusters in the dendrogram was identified without high distortion of information between original matrix and cophenetic matrix based on the cophenetic coefficient value of 0.86 , confirming that $86 \%$ of the original similarity data were well reproduced.

The Euclidean distance varied from $12 \%$ for the $\mathrm{H}, \mathrm{D}$, I and $\mathrm{K}$ subgroup (highest similarity) to $54 \%$ associated to isolated $\mathrm{G}$ group with the other study areas. Comparing the result of the generated cluster after treating data with PCA to that of the first approach 


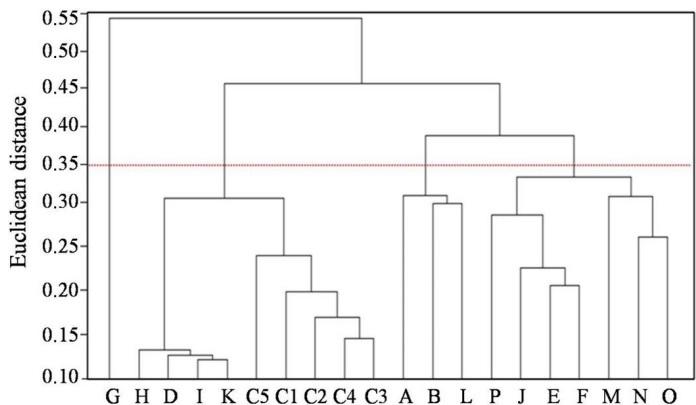

Figure 6. Dendrogram of the urban afforestation floristic similarity of the twenty municipalities in the southeastern region of Brazil after the application of PCA. Caption: A: Salto da Pirapora; B: Garça; C1: Arcos; C2: Divinópolis; C3: Formiga; C4: Itaúna; C5: Pará de Minas; D: Nova Iguaçu; E: Ribeirão Preto; F: Uberlândia; G: São Paulo; H: Jacareí; I: Tijuca; J: Assis; K: Rio de Janeiro; L: Ipiranga; M: Jerônimo Monteiro; N: Vargem Alta; O: Cachoeiro do Itapimirim; and P: São João Evangelista.

(simple method), it could be inferred that there was relative improvement in the clustering resulting from the fact that it was able to unite floristically similar environments in a more appropriate way, as they are between municipalities neighboring to their respective states (Figure 6).In additions, the fact that PCA simplifies the set of variables with the purpose of retaining the maximum information in the estimation order in terms of the total variation contained in data could also be consider. Therefore, the total variability contained in the original variables is equal to the total variability contained in the principal components (Ferreira, 2011).

A similar result was reported by Ferreira et al. (2008), in which the authors studied the floristic similarity of forest fragments in different Brazilian regions through the application of PCA prior to cluster analysis and concluded that this methodology has potential to be used to investigate forest fragment similarity, since it contributes to refining the original data, thus enabling greater consistency by cluster analysis.

\section{CONCLUSIONS}

There is greater occurrence of species belonging to Fabaceae family in the urban afforestation of cities in southeastern Brazil; however, predominance of exotic species over native species was observed.
Licania tomentosa, Caesalpinia pluviosa, Ficus benjamina, Tabebuia heptaphyla, Hibiscus rosa sinensis and Leucaena leucocephalla are the most significant species for similarity among states of Southeastern Brazil, in which the greatest floristic similarities among study studied areas were found for municipalities geographically located closer to each other.

Data ordering procedure by Principal Component Analysis has proven to be an adequate technique to improve the consistency of clusters in comparative studies of floristic similarity in the urban afforestation of cities.

\section{ACKNOWLEDGEMENTS}

We thank UEAP (Universidade do Estado do Amapá).

\section{SUBMISSION STATUS}

Received: 07 july, 2017

Accepted: 14 feb., 2018

\section{CORRESPONDENCE TO}

\section{Ronaldo Oliveira dos Santos}

Universidade do Estado do Amapá -

UEAP, Av. Presidente Vargas, 650, Centro,

CEP 68901-262, Macapá, AP, Brasil

e-mail: santosro.ueap@gmail.com

\section{REFERENCES}

Angiosperm Phylogeny Group - APG III. An update of the Angiosperm Phylogeny Group classification for the orders and families of flowering plants: APG III. Botanical Journal of the Linnean Society 2009; 161(2): 105-121. http:// dx.doi.org/10.1111/j.1095-8339.2009.00996.x.

Benatti DP, Tonello KC, Adriano-Júnior FC, Silva JMS, Oliveira IR, Rolim EN et al. Inventário arbóreo-urbano do município de Salto de Pirapora, SP. Revista Árvore 2012; 36(5): 887-894. http://dx.doi.org/10.1590/S010067622012000500011 .

Brandão IM, Gomes LB, Silva NCAR, Ferraro AC, Silva AG, Gonçalves FG. Análise quali-quantitativa da arborização urbana do município de São João Evangelista-MG. Revista da Sociedade Brasileira de Arborização Urbana 2011; 6(4): 158-174.

Castro ASF, Moro MF, Rocha FCL. Plantas dos espaços livres da Reitoria da Universidade de Fortaleza (UNIFOR), 
Ceará, Brasil. Revista Brasileira de Biociências 2011; 9(1): 126-129.

Cupertino MA, Eisenlohr PV. Análise florística comparativa da arborização urbana nos campi universitários do Brasil. Bioscience Journal 2013; 29(3): 739-750.

Faria JLG, Monteiro EA, Fisch STV. Arborização de vias públicas do município de Jacareí-SP. Revista da Sociedade Brasileira de Arborização Urbana 2007; 2(4): 20-33.

Felfili JM, Carvalho FA, Libano AM, Venturoli F, Pereira BASP, Machado ELM. Análise multivariada: princípios e métodos em estudos de vegetação. In: Felfili JM, Eisenlohr PV, Melo MMRF, Andrade LA, Meira-Neto JAA, editores. Fitossociologia no Brasil: métodos e estudos de casos. Viçosa: Editora UFV; 2011. p. 122-155.

Ferreira DF. Estatística multivariada. Lavras: UFLA; 2011. 675 p.

Ferreira RLC, Mota AC, Silva JAA, Marangon LC, Santos ES. Comparação de duas metodologias multivariadas no estudo de similaridade entre fragmentos de Floresta Atlântica. Revista Árvore 2008; 32(3): 511-521. http:// dx.doi.org/10.1590/S0100-67622008000300012.

Fischer LK, Rodorff V, Lippe MV, Kowarik I. Drivers of biodiversity patterns in parks of growing South American megacity. Urban Ecosystems 2016; 9(1): 1-20.

Forzza RC, Stehmann JR, Nadruz M, Filardi FLR, Costa A, Carvalho-Júnior AA et al. Lista de Espécies da Flora do Brasil. Rio de Janeiro: Jardim Botânico do Rio de Janeiro; 2010.

Freitas WK, Pinheiro MAS, Abrahão LLF. Análise da arborização de quatro praças no bairro da Tijuca, RJ, Brasil. Floresta e Ambiente 2015; 22(1): 23-31. http:// dx.doi.org/10.1590/2179-8087.025612.

Gonçalves W, Paiva HN. Árvores para ambiente urbanos. Viçosa: Aprenda Fácil; 2004. 242 p. (Coleção Jardinagem e Paisagimo, vol. 2).

Lorenzi H. Árvores brasileiras: manual de identificação e cultivo de plantas arbóreas nativas do Brasil. 5. ed. Nova Odessa: Platarum; 2008. 384 p.

Mazioli BC. Inventário e diagnóstico da arborização urbana de dois bairros da cidade de Cachoeiro do Itapemirim, ES. Jerônimo Monteiro: Universidade Federal do Espírito Santo; 2012.

Missouri Botanical Garden - MOBOT. W3 Specimen Data Base [online]. St. Louis: Mobot; 2017 [cited 2017 Apr 22]. Available from: http://www.mobot.org/plantscience/ W3T/Search/vas.html

Monteiro KL, Oliveira C, Silva BMS, Môro FV, Carvalho DA. Caracterização morfológica de frutos, de sementes e do desenvolvimento pós-seminal de Licania tomentosa (Benth.) Fritsch. Ciência Rural 2012; 42(1): 90-97. http:// dx.doi.org/10.1590/S0103-84782011005000147.

Nunes RL, Marmontel CVF, Rodrigues JP, Melo AGC. Levantamento qualiquantitativo da arborização urbana do bairro Ferraropólis na cidade de Garça-SP. Revista da Sociedade Brasileira de Arborização Urbana 2013; 8(1): 65-74.

Oksanen J, Blanchet FG, Kindt R, Legendre P, Minchin $\mathrm{PR}, \mathrm{O}$ 'Hara RB, et al. Vegan: community ecology package: $R$ package version 2.0-9. Vienna: R Development Core Team; 2013.

Oliveira AFD, Pereira JAA, Coelho SJ, Pereira GDA. Diagnóstico parcial da arborização viária sob rede elétrica na região oeste de Minas Gerais. Pesquisa Florestal Brasileira 2016; 36(85): 31-40. http://dx.doi.org/10.4336/2016. pfb.36.85.749.

Orfrini AC, Angelis BLD, Angelis-Neto G, Barros RA. Levantamento florístico do Campus-sede da Universidade Estadual de Maringá, Paraná. In: Anais do X Congresso Brasileiro de Arborização Urbana [CD-ROM]; 2006; Maringá. Maringá: Sociedade Brasileira de Arborização Urbana; 2006 [cited 2017 Apr 22]. Available from: http:// www.mobot.org/plantscience/W3T/ Search/vas.html

R Development Core Team. $R$ : a language and environment for statistical computing [software]. Vienna: R Foundation for Statistical Computing; 2014 [cited 2014 Jan 15]. Available from: http://www.R-project.org

Reflora. Lista de Espécies da Flora do Brasil [online]. Rio de Janeiro: Jardim Botânico do Rio de Janeiro; 2017 [cited 2017 June 9]. Available from: http://floradobrasil. jbrj.gov.br/

Rocha RT, Leles PSS, Oliveira-Neto SN. Arborização de vias públicas em Nova Iguaçu, RJ: o caso dos bairros rancho novo e centro. Revista Árvore 2004; 28(4): 599-607. http://dx.doi.org/10.1590/S0100-67622004000400014.

Romani GN, Gimenes R, Silva MT, Pivetta KFL, Batista GS. Análise quali-quantitativa da arborização na praça XV de novembro em Ribeirão Preto - SP, Brasil. Revista Árvore 2012; 36(3): 479-487. http://dx.doi.org/10.1590/ S0100-67622012000300010.

Rossatto DR, Tsuboy MSF, Frei F. Arborização urbana na cidade de Assis-SP: uma abordagem quantitativa. Revista da Sociedade Brasileira de Arborização Urbana 2008; 3(3): 1-16.

Rossetti AIN, Tavares AR, Pellegrino PRM. Inventário arbóreo em dois bairros Paulistanos, Jardim da Saúde e Vila Vera, localizados na subprefeitura de Ipiranga. Revista Árvore 2010; 34(5): 889-898. http://dx.doi.org/10.1590/ S0100-67622010000500014.

Scaramussa LM. Levantamento quali-quantitativo da arborização urbana e percepção dos moradores da cidade de Vargem Alta - ES. Jerônimo Monteiro: Universidade Federal do Espírito Santo; 2013.

Silva AG, Cardoso AL, Raphael M. Diagnóstico qualiquantitativo da arborização viária da cidade de Jerônimo Monteiro, ES. Enciclopédia Biosfera 2012; 8(14): 1179-1188.

Silva EM, Silva AM, Melo PH, Borges SSA. Estudo da arborização urbana do bairro Mansour, na cidade de Uberlândia-MG. Caminhos de Geografia 2002; 3(5): 73-83. 
Silva JG, Perelló LFC. Conservação de espécies ameaçadas do Rio Grande do Sul através de seu uso no paisagismo. Revista da Sociedade Brasileira de Arborização Urbana 2010; 5(4): 1-21.

Souza AL, Ferreira RA, Mello AA, Plácido DR, Santos CZA, Graça DAS et al. Diagnóstico quantitativo e qualitativo da arborização das praças de Aracaju, SE. Revista Árvore 2011;35(6): 1253-1263. http://dx.doi.org/10.1590/S010067622011000700012 .
Souza RC, Cintra DP. Arborização viária e conflitos com equipamentos urbanos no bairro da Taquara, RJ. Floresta e Ambiente 2007; 14(1): 25-33.

Souza SCPM, Silva AG, Franco GADC, Ivanauskas NM. A vegetação secundária em um fragmento florestal urbano: influência de exóticas invasoras na comunidade vegetal. Revista do Instituto Florestal 2016; 28(1): 7-35.

Zar JH. Biostatistical analysis. 5th ed. New Jersey: Prentice Hall Inc., Upper Saddle River; 2009. 943 p. 